УДК 553. 98(479.24): 550.8.072

\title{
ОЦЕНКА НЕФТЕГАЗОНОСНОСТИ ЛОКАЛЬНЫХ ПОДНЯТИЙ СЕВЕРО-АБШЕРОНСКОЙ ЗОНЫ НА ОСНОВЕ ПЕТРОФИЗИЧЕСКИХ ПАРАМЕТРОВ (НА ПРИМЕРЕ ЛОКАЛЬНЫХ ПОДНЯТИЙ ГОШАДАШ-АГБУРУН-ДЕНИЗ-ДАРВИН КЮПЕСИ-ГЮРГЯН-ДЕНИЗ)
}

\author{
Мухтарова Хураман Зиядхан гызы1', \\ mukhtarova.khuraman@mail.ru \\ Насибова Гюльтар Джумшуд гызы 1 , \\ gultar_nasibova_1@yahoo.com \\ 1 Азербайджанский Государственный университет нефти и промышленности,
Азербайджан, AZE1010, г. Баку, пр. Азадлыг, 34.
}

\begin{abstract}
Рассмотрены особенности изменения петрофизических параметров (гранулометрический состав и карбонатность) пород локальных поднятий Гошадаш, Агбурун-дениз, Дарвин кюпеси и Гюргян-дениз в интервале глубин 400-2650 м, и построены их диаграммы. Анализ изменения петрофизических особенностей пород по площади и глубине дает возможность определить изменение их коллекторских свойств, а также относительно объективно оценить содержание флюидов и перспективы нефртегазоносности резервуаров. Авторами по отдельности были проанализированы изменения петрофизических свойств пород площадей Гошадаш, Агбурун-дениз, Дарвин кюпеси и Гюргян-дениз до глубины 2650 м и их влияние на пористость и проницаемость. По анализу гистограмм, построенных на основании петрофизических данных, в разрезе площадей по глубине отмечаются различные процентные соотношения как псефитовых, псаммитовых, алевритовых и пелитовых фации терригенного происхождения, так и карбонатных фрации. В осадочной толще, как правило, между карбонатностью, глинистостью и коллекторскими свойствами наблюдается обратная связь, а со степенью отсортированности - прямая. Эта закономерность нарушается в исключительных случаях, когда качество коллектора, вероятно, связано с увеличением вязкости в породах и образованием вторичной пористости. Образование вторичной пористости на относительно больших глубинах, 8 связи с этим не исключает наличия углеводородных скоплений.
\end{abstract}

Актуальность. Североабшеронская зона поднятий, расположенная вблизи с богатыми нефртегазоконденсатными месторождениями, охватывает большую территорию, берущую начало с северо-запада Абшеронсокого полуострова и простирающуюся в юго-восточном направлении. Здесь расположены морские поднятия Гошадаш, Агбурун-дениз, Дарвин кюпеси и Гюргян-дениз, являющиеся территорией исследования. Продуктивная толща, являющаяся основным нефртегазоносным комплексом, расположена на относительно небольшой глубине, в пределах досягаемости современной техники. Построение и анализ петрофризических моделей может сыграть важную роль в прогнозировании перспектив нефртегазоносности продуктивной толщи и нижележащих отложений, а также стать основой обнаружения новых нефтегазовых скоплений и увеличения добычи нефти.

Цель: изучение литоффациальных и коллекторских свойств пород по глубине на основании петросииических моделей, построенных согласно геолого-геофизическим данным и данным скважин.

Объекты: отложения продуктивной толщи площадей Гошадаш, Агбурун-дениз, Дарвин кюпеси и Гюргян-дениз.

Методы. Коллекторские свойства отложений интервала глубин 400-2650 м площадей Гошадаш, Агбурун-дениз, Дарвин кюпеси и Гюрган-дениз были изучены на основании исследования в лабораторных условиях образцов керна, отобранных в скважинах. Вышеуказанный интервал исследований был разбит на несколько мелких интервалов, каждый величиной в 150 м, и из каждого интервала было отобрано от 20 до 40 образцов керна, проведён анализ, установлены их гранулометрический состав, процентное содержание карбонатов, пористость, проницаемость. В результате данного анализа для каждого из интервалов в 150 м были представлены средние значения для вышеназванных параметров, на основании которых нами были построены гистограммы.

Результаты. Между коллекторскими свойствами и карбонатностью, глинистостью пород в изучаемом интервале глубин на площадях Гошадаш, Агбурун-дениз, Дарвин кюпеси, Гюрган-дениз наблюдается в основном обратное соотношение. В особенностях изменения петросизических параметров отложений продуктивной толщи по глубине на структурах Гошадаш, Агбурун-дениз, а также на месторождениях Дарвин кюпеси, Гюрган-дениз, за исключением некоторых коротких интервалов, не наблюдается какой-либо закономерности (т. е. линейности). На основании фонтанов нефрти дебитом 42 m/сут. из подкирмакинской свиты в скважине 726, пробуренной на месторождении Дарвин кюпеси, а также дебитом 20 m/сут. из кирмакинской свиты в скважине 813, полученной во время испытательных работ $10 \mathrm{~m} / \mathrm{cym}$. нефти из подкирмакинской свиты в скважине 7, пробуренной на месторождении Гюрган-дениз, и идентичной степени изменения коллекторских свойств пород в структурах Гошадаш и Агбурун-дениз, расположенных на той же антиклинальной линии, что и вышеуказанные месторождения, можно предположить наличие и в этих структурах углеводородных скоплений в одноименных отложениях.

Ключевые слова:

Отложения, петрофизические параметры, пелиты, псаммиты, алевриты, карбонатность, пористость, проницаемость.

\section{Введение}

С тектонической точки зрения Абшеронский архипелаг охватывает северо-западную часть структурной мегаседловины субмеридионального направления, образовавшейся между складчатыми системами
Большого Кавказа и Копетдага, отделяющие ЮжноКаспийскую впадину от Средне-Каспийской [1].

Окруженная богатыми нефтегазоконденсатными месторождениями Северо-Абшеронская зона поднятий занимает большую территорию Абшеронского 
полуострова, протянувшуюся в направлении с северозапада на юго-восток. В эту зону входят складки: Гошадаш, Агбурун-дениз, Абшерон кюпеси, Шимали Абшерон, Генби Абшерон, Хезри, Гилавар, Арзу, Гетлгюну, Вусал, Севиндж, Дан улдузу, Новханы, Айпара, Генджлик, Эшрефи, Гелебе, Зирве, Хамдам, Гарабаг (рис. 1) [2, 3].

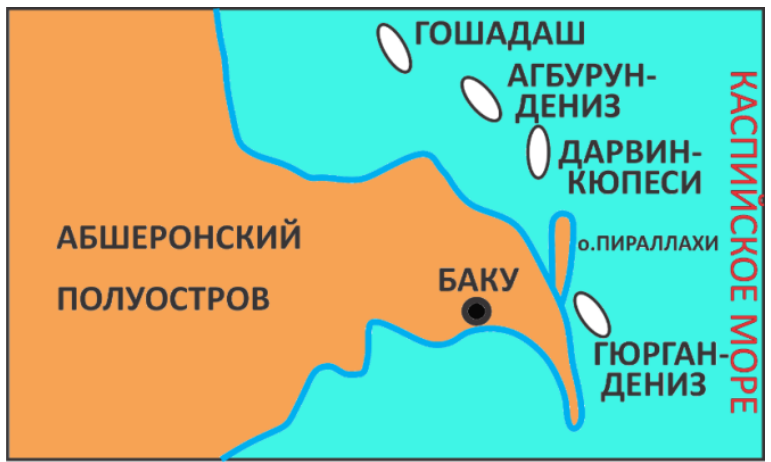

Puc. 1. Карта распределения локальных структур Северо-Абшеронского архипелага

Fig. 1. Map of distribution of local structures of the North Absheron archipelago

Складка Дарвин кюпеси берет свое начало в восточной части Северо-Абшеронского архипелага и протягивается в общекавказском направлении. Данная структура относится к Приабшеронской полузоне Абшероно-Балханской зоны поднятий [4].

В геологическом строении месторождения Дарвин кюпеси участвуют миоценовые-четвертичные отложения. Диатомовая свита (средний, нижний миоцен $\mathrm{N}_{1}{ }^{2+3}$ ) сложена из песчано-слюдовых глин. Вскрытая мощность до $100 \mathrm{M}$.

Имеющий максимально вскрытую мощность в 50 м ярус понта, как и по всему Абшеронскому полуострову, литологически представлен глинами с редкими прослойками песков. Отложения понта выклиниваются в направлении к своду структуры, и в результате породы продуктивной толщи (ПТ) залегают непосредственно на пластах диатома. Имеющие максимальную мощность 1900 м породы ПТ представлены песками, песчаниками, алевритами и глинами. В результате денудации свода складки отложения ПТ представлены лишь свитами своего нижнего отдела, из которых нефтеносными являются только подкирмакинская (ПКС) и кирмакинская (КС) свиты.

Отложения акчагильской и абшеронской свит полосой охватывают восточное и западное крылья складки. Акчагильский пласт представлен глинами с пропластками песчаников небольшой мощности, в его разрезе также присутствуют слои вулканического пепла. Абшеронский ярус представлен в основном известняками.

Древнекаспийские отложения сложены гравием, конгломератами, ракушечником и песками. Разрез современных каспийских отложений представлен чередованием ракушечника и кварцевых песков.

Ось брахиантиклинальной структуры Дарвин кюпеси простирается в субмеридиональном направле- нии, и сама структура осложнена многочисленными продольными и поперечными разломами (рис. 2, $a, 6$ ).

Здесь фонтаном нефти, полученным в 1950 г. из кирмакинской свиты в скважине 735 (КС) на западном крыле структуры, было открыто месторождение и началась его разработка. Дебит скважины составлял 5 т/сут. В том же году пробуренная на этом участке скважина 726 фонтанировала из отложений ПКС дебитом 42 т/сут, а скважина 813 из отложений КС дебитом 20 т/сут $[5,6]$.

Нефтеносность северного и северо-восточного участков была выявлена в 1955-1962 гг. в результате проведенных разведочных работ. В соответствии с пространственным распределением залежей нефти по пластам, структура Дарвин кюпеси была разделена на четыре зоны: южная, центральная, северная и северовосточная. Основными эксплуатационными объектами месторождения являются КС и ПКС.

Следует отметить, что в качестве эксплуатационного объекта КС была разделена на две части: верхнюю - $\mathrm{KC}_{\text {в }}$ и нижнюю - $\mathrm{KC}_{\mathrm{H}}$. В первые годы разработки суточная добыча нефти составляла: по $\mathrm{KC}_{\mathrm{B}}-$ 35-41 т, по $\mathrm{KC}_{\mathrm{H}}-12-21$ т, а по ПКС - 6,8 т.

Надо отметить, что до недавнего времени эксплуатация нефтяных пластов ПКС велась только на южном и центральном участках структуры $[7,8]$.

Связанное с самостоятельным поднятием месторождение Гюрган-дениз расположено в западной части Абшеронского архипелага, с тектонической точки зрения на юго-восточном крыле складки Южный Пираллахи (рис. 1). Гюрган-дениз отделяется от Южного Пираллахи неглубокой седловиной, осложненной тектоническим нарушением амплитудой 200-250 м.

Из четырех скважин, пробуренных на месторождении, скважина 7 в 1946 г. вскрыла ПКС и в результате опробования с суточным дебитом в 10 т месторождение было введено в эксплуатацию в 1947 г., а разработка началась с 1950 г.

В геологическом разрезе месторождения Гюргандениз присутствуют отложения понта, ПТ, акчагиля, абшерона и четвертичного периода. На юго-западном крыле складки песчанистость отложений калинской свиты (КаС) возрастает и встречаются слои нефтеносных песков. Эти слои, выклиниваясь на близких расстояниях, образуют линзовидные залежи. В северовосточном крыле ПКС была вскрыта ограниченным количеством скважин и по литофациальному составу характеризуется плотными высококарбонатными породами. Эти породы общей мощностью в 140 м являются нефтеносными на юго-западном крыле и делятся на три разрабатываемых объекта: ПК-1, ПК-2, ПК-3 $[9,10]$.

КС представлена чередованием песчаника, слоистого, мелкозернистого песка и глин. Песчанистость этих пород возрастает от северо-восточного крыла складки к юго-западному, а также от кровли к подошве. Следует отметить, что в разрезе этих отложений КС также выделены три продуктивных горизонта: КС-1, КС-2, КС-3. Песчанистость растет в юговосточном и северо-западном направлениях. Общая мощность КС на территории месторождения достигает $273 \mathrm{M}$. 

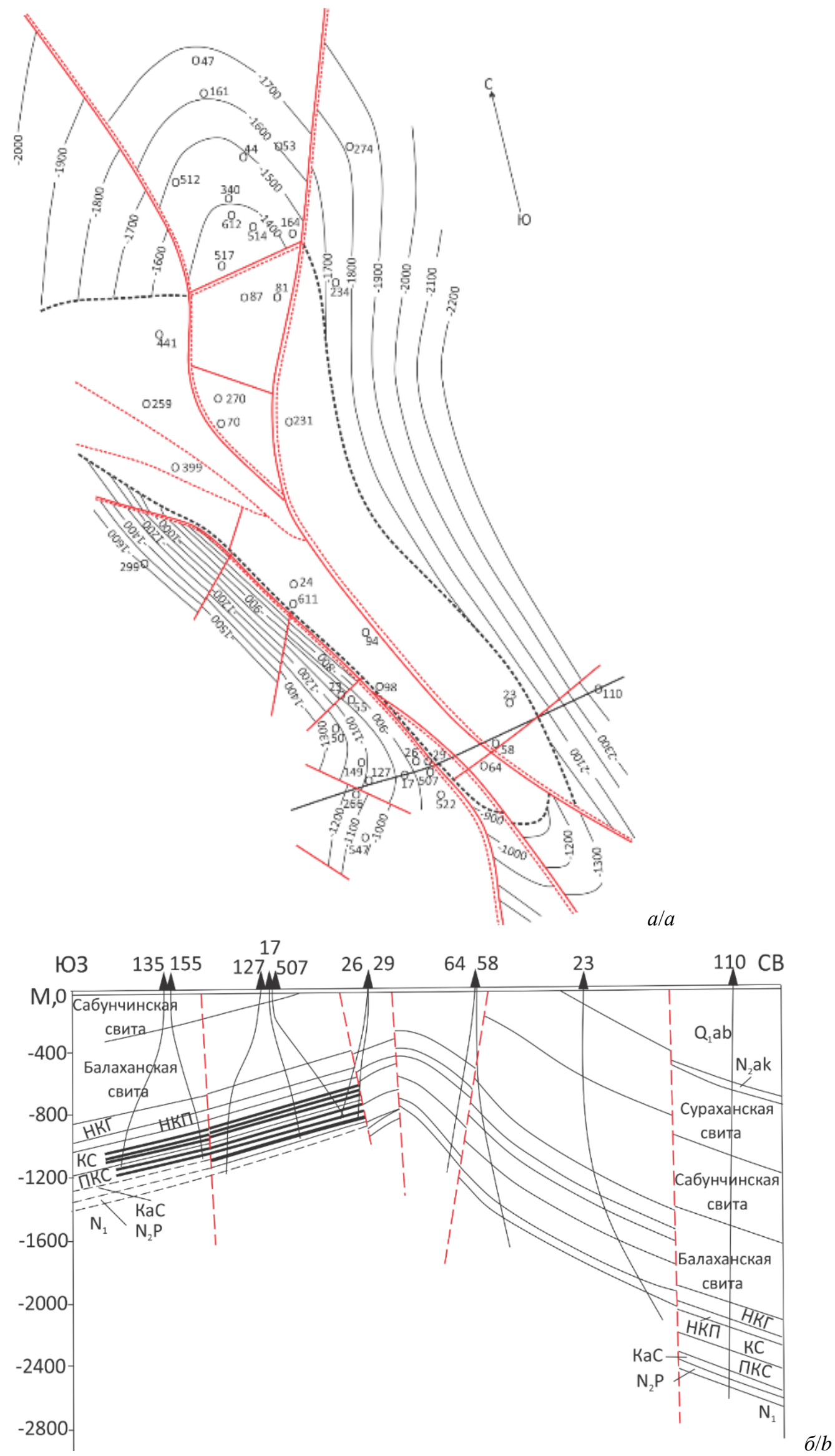

Pис. 2. Месторождение Дарвин кюпеси: а) структурная карта по кровли ПКС; б) геологический профиль по линии I-I Fig. 2. Deposit Darwin kyupesi: a) structural map for the roof of the PKS; b) geological profile along the line I-I 


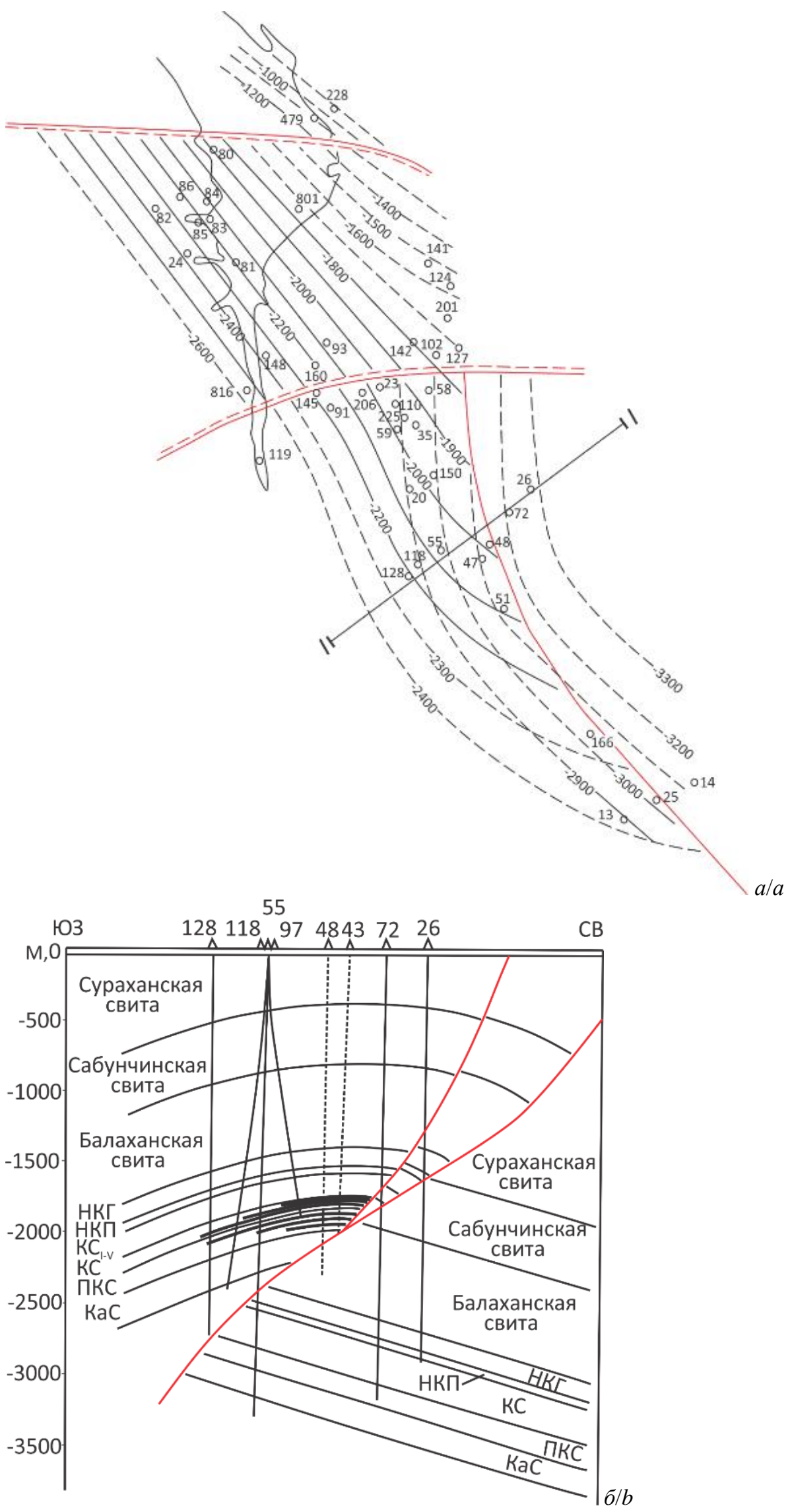

Pис. 3. Гюрган-дениз: а) структурная карта по кровли КаС ПТ; б) профиль по линии I-I Fig. 3. Gurgan-deniz: a) structural map for the roof KaS PT roof; b) profile along line I-I 
Надкирмакинская песчаная (НКП) свита представлена чередованием средне-, крупнозернистых песков и песаников с пропластками глин. Мощность достигает 40 м.

Надкирмакинская глинистая (НКГ) свита сложена глинами с песчаными пропластками. Мощность 195 м.

Свита «фасиля» мощностью в 85 м представлена песками с тонкими пропластками средне-, крупнозернистых песков и прослойками глин.

Балаханская свита характеризуется чередованием глин со средне- и мелкозернистыми песками. Мощность достигает $610 \mathrm{M}$.

Сабунчинская свита мощностью до 400 м состоит из чередования мелкозернистых песков с глинами.

Сураханская свита составлена глинами с мощными пластами мелкозернистых песков, обнажающихся в сводовой части складки. Мощность достигает 310 м.

Отложения акчагильского и абшеронского ярусов распространены от сводовой части складки к крыльям и в погребенной южной периклинали [10].

Поперечный разрыв амплитудой в 80 м, разделяющий месторождение Гюрган-дениз на два участка, имеет сбросовый характер (рис. $3, a, \sigma)$.

Следует отметить, что юго-западное крыло складки Гюрган-дениз надвинуто на северо-восточное по продольному разрыву с вертикальной амплитудой в 750-800 м. Амплитуда надвига, увеличиваясь в южном направлении, достигает 1000 м.

Несмотря на то, что южная часть юго-западного надвинутого крыла КС (КСв-1, КСв-2, КСв-3) и КаС являются нефтеносными, запасы залежей, относящихся к данным свитам, несущественны.

В пределах как северного, так и южного участков этого же крыла ПКС является нефтеносной.

Нефтяные залежи КаС связаны с отдельными песчаными линзами, которые рассматриваются в качестве литологических ловушек.
На северо-восточном крыле складки (под надвигом) из двух скважин, вскрывших нижний отдел ПТ, была получена нефть [11].

Ловушки, в которых сформировались нефтяные залежи складки Гюрган-дениз, относятся к тектонически экранированным, литологически ограниченным и смешанным типам [8].

Поднятие Агбурун-дениз было обнаружено методом сейсморазведки в 1948 г. В последующие годы (1960-1980 гг.) наличие структуры Агбурун-дениз, расположенной вблизи юго-западного крыла Абшерон кюпеси, было подтверждено в результате проведенных с перерывами геофизических исследовательских работ [5].

Изменение петрофизических особенностей пород по глубине на изучаемых площадях.

Как известно, анализ изменения петрофизических особенностей пород по площади и глубине дает возможность определить изменение коллекторских свойств в тех же направлениях, а также оценить флюидное содержание природных резервуаров и перспективы их нефтегазоносности [12, 13].

Учитывая вышеуказанное, с целью изучения изменения петрофизических свойств пород на площадях Гошадаш, Агбурун-дениз, Дарвин-дениз, Гюргандениз до глубины 2800 м и и их влияния на пористость и проницаемость были построены и проанализированы соответствующие диаграммы для площадей по отдельности.

Как видно из гистограммы для площади Гошадаш, в ее геологическом разрезе присутствуют как псефитовые, псаммитовые, алевритовые, пелитовые фации терригенного происхождения, так и карбонатные фации различного содержания по глубине (рис. 4) [14].

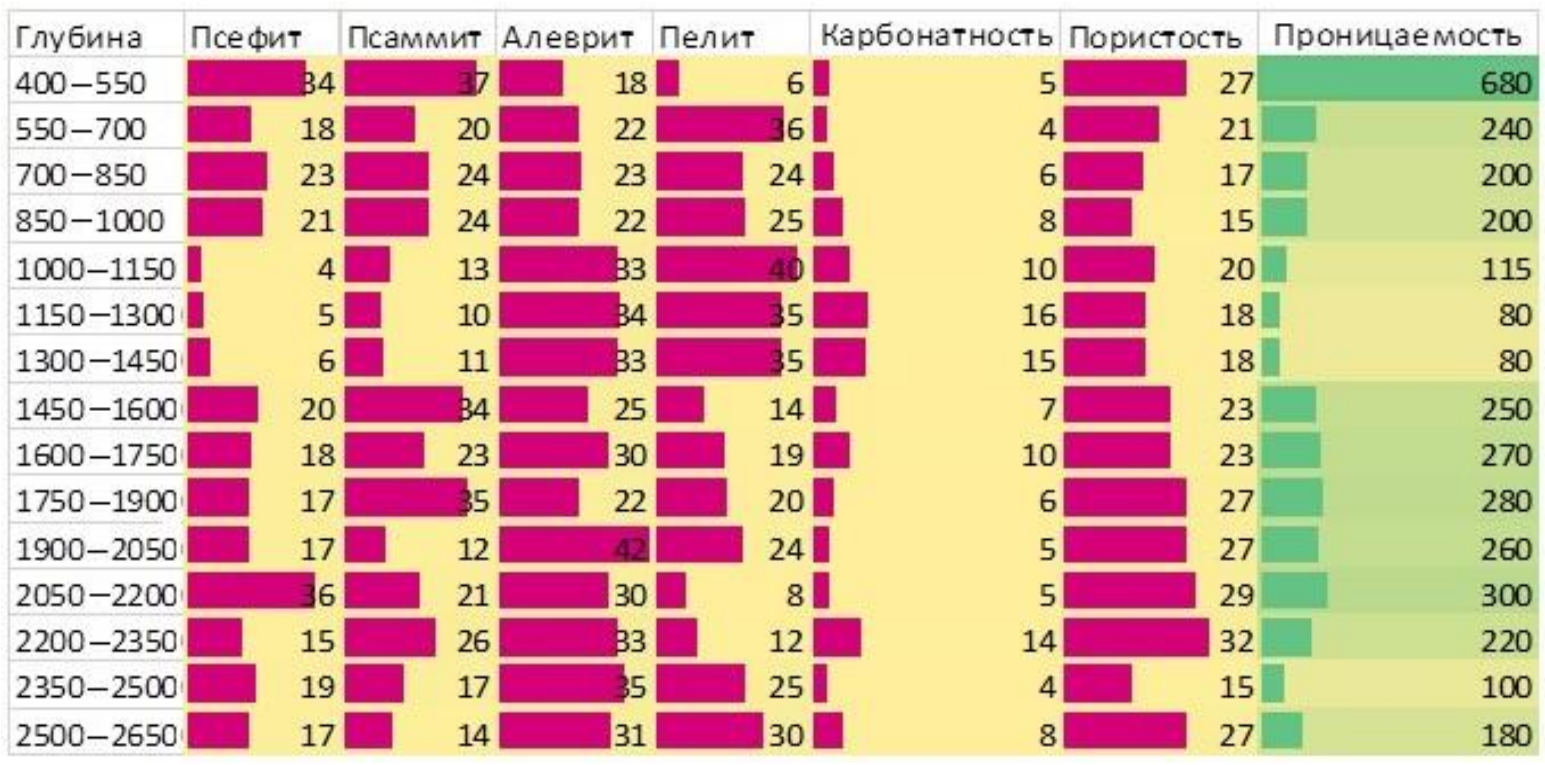

Рис. 4. Гистограммы петрофизических особенностей пород площади Гомадаш от глубины. Деление на свиты: 400-1300 - сураханская, сабунчинская, балаханская, НКГ, НКП, КС; 1200-2100 - ПКС, КаС, понтская $\left(N^{2} p\right)$; 2100-2600-Мезозой (Mz)

Fig. 4. Histograms of petrophysical features of rocks Goshadash square from the depth. Division into suites: 400-1300Surakhan, Sabunchu, Balakhan, NKQ, NKP, KS, 1200-2100-PKS, KaS, pont (N² p); 2100-2600-Mesozoic (Mz) 
Из гистограммы видно, что гранулометрический состав пород, сформировавшихся в интервале глубин 400-550 м, представлен до 34-36 \% псефитовыми, на $37 \%$ псаммитовыми, $18 \%$ алевритовыми, до 6-8\% пелитовыми фациями, а карбонатность составляет 5 \%. Породы данного состава характеризуются пористостью в 26-27 \%, и проницаемостью 670-680 мД.

Слои пород, расположенные на следующем интервале 550-700 м, составлены в среднем на $18 \%$ псефитами, $20 \%$ псаммитами, $22 \%$ алевритами, $36 \%$ пелитами, карбонатность 4-6\%. В связи с резким увеличением пелитов и относительно малым ростом карбонатности наблюдается падение пористости до 21 \%, а проницаемости - до 240 мД. Как отмечалось, причиной тому является рост карбонатности, пелитовой фации пород, а также относительно резкое уменьшение псефитовой фации.

Исследования показали, что породы интервала глубин 700-850 м характеризуются следующим составом: псефиты - $23 \%$, псаммиты - 24-25\%, алевриты и пелиты - 23-24 \%, карбонатность - 6-8 \% В свою очередь, пористость составляет $17 \%$, а проницаемость чуть более 200 мД.

Уменьшение проницаемости связано с увеличением карбонатности и гранулометрически плохой отсортированностью пород $[15,16]$.

Слои пород, расположенные в интервале глубин 850-1000 м, имеют следующий гранулометричесий состав: $21 \%$ - псефиты, до 24-26 \% - псаммиты, $22 \%$ алевриты, $25 \%$ - пелиты. Как и на предыдущем интервале карбонатность здесь составляет $8 \%$. Пористость относительно предыдущего интервала (700-850 м) уменьшилась до $15 \%$, а проницаемость, незначительно уменьшившись, составила чуть более 200 мД.

В интервале 1000-1150 м комплексы пород состоят на 4-6 \% из псефитов, 13-15\% - псаммитов, до $33 \%$ алевритов и 40-42\% - пелитов. Карбонатность выросла до $10 \%$. В результате пористость этих пород составляет $20 \%$, а проницаемость колеблется между 110-115 мД. Исследования показали, что при относительно высокой пористости настолько низкие величины проницаемости можно объяснить плохой отсортированностью зерен пород и увеличением карбонатности [14].

Комплексы пород, слагающие интервал в 1150-1300 м, до 5-6 \% состоят из псефитов, 10-11 \% - псаммитов, 34-35 \% - алевритов и приблизительно на столько же - пелитов. Карбонатность - до 16 \%. Надо отметить, что по сравнению с предыдущими интервалами этот показатель карбонатности достиг максимальных значений. Породы такого состава характеризуются уменьшением значений пористости до 17-18\%, а проницаемости - приблизительно, до 70-80 мД. Основными факторами, способствующими таким низким показателям проницаемости, являются высокое содержание карбонатности и пелитовой фации, а также падение содержания псефитовой фации до минимума в 5-6 \%, и это отрицательно влияет на проницаемость.

На интервале глубин 1300-1450 м породы составлены на $6 \%$ из псефитов, $11 \%$ - псаммитов, $33 \%$ - алевритов и $35 \%$ - пелитов. Карбонатность - около $15 \%$. Пористость пород данного состава - 22-23\%, а проницаемость - 240-250 мД.

На интервале глубин 1450-1600 м породы составлены на 20-22 \% из псефитов, 34-36 \% - псаммитов, $25-27 \%$ - алевритов и 14-16 \% - пелитов. Карбонатность - около 7-9 \%. Пористость пород данного состава - 22-23 \%, а проницаемость - 240-250 мД.

Комплексы пород, сформировавшиеся в интервале глубин 1600-1750 м, характеризуется следующим гранулометрическим составом: псефиты - $18 \%$, псаммиты - $23 \%$, пелиты - 19\%, алевриты - 30-33\%. При карбонатности в $10 \%$ пористость составляет $23 \%$, а проницаемость - 260-270 мД.

Породы интервала 1750-1900 м характеризуются следующим составом: псефиты - 17-18 \%, псаммиты - $35 \%$, алевриты - $22 \%$, пелиты - до $20 \%$. Карбонатность составляет - 6-7 \%, пористость - 26-27 \%, а проницаемость - 270-280 мД.

На глубинах 1900-2050 м фации псефита и псаммита составляют 17 и $12 \%$, алевриты - 42-43\%, пелиты - 24-25\%, а карбонатность - $5 \%$. Пористость этого комплекса пород составляет 26-27 \%, а проницаемость достигает 250-260 мД. Относительно низкая проницаемость объясняется высоким содержанием пелитовой и алевритовой фаций.

Гранулометрический состав пород, сформировавшихся на глубинном интервале от 2050 до 2200 м, характеризуется следующим образом: псефиты - 36-37 \%, псаммиты - 21-23 \%, алевриты - до 30-32 \%, всего 8-9 \% пелиты. Карбонатность идентична предыдущим интервалам и составляет $5 \%$. Относительно высокое процентное содержание псефитовой фации, по сравнению с пелитовой и карбонатностью, стало причиной роста коэффициента пористости этих пород. Однако, несмотря на это, проницаемость пород характеризуется незначительным увеличением и достигает 300 мд.

В отложениях, соответствующих интервалу глубин 2200-2350 м, псефитовая фация составляет 15-17\%, псаммитовая - 26-29 \%, алевритовая - 33-35\%. Процент пелитовой фации увеличивается, достигая $12-15 \%$. Карбонатность резко увеличивается до $14 \%$. Несмотря на то, что пористость увеличивается до 31-32\%, проницаемость уменьшается до 210-220 мД. Наиболее вероятно, что основной тому причиной является резкий рост карбонатности и уменьшение содержания псефитовой фации.

На интервале глубин 2350-2500 м содержание пелитов, незначительно увеличиваясь, достигает $19 \%$, тогда как содержание псаммитов падает до 17 \%. Содержание алевритов и пелитов увеличивается и достигает, соответственно, 35 и $25 \%$. Карбонатность же пород резко падает, достигая 4-6\%. Пористость интервала составляет всего $15 \%$, а проницаемость колеблется между 90-100 мД.

На интервале 2500-2650 м состав пород представлен 17 \% псефитами, 14 \% псаммитами, $31 \%$ алевритами и $30 \%$ пелитами. Карбонатность увеличивается до 8 \%. В результате пористость составляет 26-27\%, а проницаемость - 170-180 мД. Относительное уве- 
личение проницаемости может быть обусловлено вторичной пористостью $[17,18]$.

При изучении изменения петрофизических свойств пород по глубине на пдощади Агбурун-дениз было выявлено, что в пластах, залегающих на глуби- нах 400-550 м, псефиты составляют $22 \%$, псаммиты - $16 \%$, алевриты - $37 \%$, пелиты - $21 \%$, а карбонатность прблизительно равна $4 \%$. При таком составе пористость пород - 26-27 \% и проницаемость - в среднем 773 мД (рис. 5).

\begin{tabular}{|l|l|l|l|l|r|r|r|}
\hline Глубина Псефит Псаммит Алеврит Пелит Карбонатность Пористость \\
\hline $400-550$
\end{tabular}

Рис. 5. Гистограммы изменения петрофизических особенностей пород площади Агбурун-дениз от глубины. Деление на свиты: 400-1200 - сураханская, сабунчинская, балаханская; 1200-2600-НКГ, НКП, КС, ПКС, КаС

Fig. 5. Histograms of changes in petrophysical features of rocks Aghburun-deniz square with the depth. Division into suites: 400-1200 - Surakhan, Sabunchu, Balakhan; 1200-2600-NKQ, NKP, KS, PKS, KaS

В осадочном комплексе следующего интервала, т. е. на глубинах 550-700 м, содержание псефитов изменяется между $23-25 \%$, псаммитов - $18 \%$, алевритов - 25-26\%, пелитов - 30-32\%, тогда как в процентном содержании карбонатов, по сравнению с предыдущим интервалом, изменений нет. Пористость таких пластов составляет 28-29\%, а проницаемость между 850-860 мд.

На интервале глубин в 700-850 м отложения характеризуются следующим образом: псефитовая и псаммитовая фации увеличиваются, на 31 и $24 \%$, алевритовая и пелитовая фации уменьшаются на 13 и $27 \%$. В условиях относительного роста карбонатности наблюдается относительное уменьшение пористости до $15-16 \%$ и резкое снижение проницаемости до 490-500 мД.

Вдоль всего интервала 850-1000 м породы характеризуются наличием псефитовой фации - $27 \%$, псаммитовой - $23 \%$, общим содержанием алевритовой и пелитовой фаций - 42-44 \%. Карбонатность пород данного интервала повторно характеризуется ростом и достигает $8 \%$. Пористость в $14-15 \%$ имеет минимальную величину именно в пределах данного интервала. Несмотря на пониженную пористость, относительно резкое сокращение пелитовой фации оказывает положительное влияние на значение проницаемости, которая, увеличиваясь, достигает 520-525 мД.

Интервалы глубин 1000-1150, 1150-1300, 1300-1450, 1600-1750 и 1750-1900 м характеризуются схожими петрофизическими показателями. В среднем эти по- роды сложены псефитами - 5-6\%, псаммитами - 13-14 \%, алевритами - $26 \%$ и на более чем на 50-52 \% пелитами. Такой высокий показатель пелитовой фации привел к резкому падению значения карбонатности (6 \%) и даже пористости (15-16 \%) с проницаемостью (до 27 мД).

Следующий интервал - 1900-2050 м - характерен повышением показателей псефитовой и псаммитовой фаций (8-16\%), резким понижением пелитов (60\%), и относительным уменьшением карбонатности (3\%), а алевриты составляют $13 \%$. В результате в данном интервале наблюдается относительный рост пористости и резкое увеличение приницаемости до отметки $320 \mathrm{мД}[19,20]$.

Кроме некоторых исключений, наблюдаются соответствующие изменения в петрофизических особенностях пород, сформировавшихся в интервалах 2050-2200, 2200-2350, 2350-2500, 2500-2650 м уменьшение содержания пелитовой фации и карбонатности сопровождается повышением пористости и проницаемости.

С целью изучения изменения петрофизических особенностей пород на площади Дарвин кюпеси по глубине были исследованы отдельные глубинные интервалы [12]. Следует отметить, что процентное содержание гранулометрического состава пород глубинного интервала 400-550 м нижеследующий: псефиты - приблизительно $2 \%$, псаммиты - 30-32\%, алевриты - 28-30\% и пелиты - до $40 \%$. Карбонатность - не выше 2-3 \%. Пористость пород такого со- 
става - до 21-22 \%, а проницаемость - до 75-80 мД (рис. 6).

В следующем интервале (550-700 м) содержание псефитов, по сравнению с предыдущим, почти не изменяется. На фоне относительного увеличения псаммитовой и алевритовой фаций, составляющих, соответственно, 36 и $45 \%$, наблюдается резкое уменьшение пелитовой фации до $15 \%$. Как видно из гисто- грамм, низкое содержание пелитовой фации в разрезе сопровождается ростом показаний пористости и проницаемости.

В интервале 700-850 м содержание псефитов составляет $2 \%$, псаммитов - $3 \%$, алевритов и пелитов в сумме $90 \%$, карбонатность - около $5 \%$. Пористость пород с таким составом - 30-31 \%, а проницаемость 70-80 мД.

\begin{tabular}{|c|c|c|c|c|c|c|c|}
\hline Глубина & Псефит & Псаммит & Алеврит & Пелит & Карбонатность & Пористость & Проницаемость \\
\hline $400-550$ & 2 & 30 & 28 & 381 & 2 & 22 & 80 \\
\hline $550-700$ & 2 & 36 & 45 & $15 \mid$ & 2 & 21 & 120 \\
\hline $700-850$ & 2 & 3 & 44 & 46 & 5 & 31 & 80 \\
\hline $850-1000$ & 2 & 10 & 56 & 27 & 5 & 33 & 170 \\
\hline $1000-1150$ & 20 & 20 & 29 & 25 & 6 & 27 & 115 \\
\hline $1150-1300$ & 20 & 20 & 29 & 25 & 6 & 27 & 115 \\
\hline $1300-1450$ & 3 & 31 & 41 & 20 & 5 & 25 & 40 \\
\hline $1450-1600$ & 4 & 20 & 40 & 26 & 10 & 23 & 115 \\
\hline $1600-1750$ & 9 & 48 & 22 & $18 \mid$ & 3 & 23 & 120 \\
\hline $1750-1900$ & 2 & 32 & 30 & 31 & 5 & 26 & 155 \\
\hline $1900-2050$ & 12 & 27 & 36 & 17 & 8 & 23 & 110 \\
\hline $2050-2200$ & 13 & 30 & 28 & 25 & 4 & 22 & 115 \\
\hline $2200-2350$ & 13 & 30 & 28 & 25 & 4 & 22 & 115 \\
\hline $2350-2500$ & 4 & 24 & 42 & 21 & 9 & 25 & 35 \\
\hline $2500-2650$ & 3 & 27 & 40 & 20 & 10 & 27 & 18 \\
\hline
\end{tabular}

Рис. 6. Гистограммы изменения петрофизических особенностей пород площади Дарвин-дениз от глубины. Деление на свиты: :400-1200 - сураханскал, сабунчинская, балаханскал, НКГ; 1200-2600-НКП, КС, ПКС, КаС, $N^{2} p$

Fig. 6. Histograms of changes in petrophysical characteristics of rocks of Darwin-deniz square with the depth. Division into suites: 400-1200 - Surakhan, Sabunchu, Balakhan, NKQ; 1200-2600-NKP, KS, PKS, KaS, $N^{2} p$

Комплексы пород глубинного интервала 850-1000 м содержат 2-3 \% псефитов, 10-12 \% псаммитов, $56 \%$ алевритов, 27-29 \% пелитов, карбонатность не изменилась. Пористость, в свою очередь, составляет $33 \%$, а проницаемость увеличивается до 170 мД.

Несмотря на рост псеффитов до 20-22 \%, псаммитов до 20-21 \%, в интервале 1000-1150 и 1150-1300 м наблюдается падение в содержании алевритов и пелитов (29 и 25 \%). Карбонатность характеризуется незначительным ростом (6 \%). Также наблюдается определенное уменьшение пористости и проницаемости.

В интервале глубин 1300-1450 м содержание псефитов составляет $3 \%$, псаммитов - $31 \%$, алевритов $41 \%$ и пелитов - $20 \%$. Карбонатность - около $5 \%$. Пористость - до 24-25 \%, а проницаемость - до 35-40 мД.

В следующем интервале - 1450-1600 м - фациальный состав пород, следующий: псефиты - 4-5\%, псаммиты - 20-22 \%, алевриты - 40-42 \%, пелиты 26-28 \%, процентное содержание карбонатности достигает $10 \%$, и несмотря на то, что это сопровождается уменьшением значений пористости, данное положение не оказало большого влияния на проницаемость.

В интервале 1600-1750 м содержание псефитов упало до $9 \%$, псаммитов - до 48-50\%, алевритов до 22-23\%, пелитов - до 18-20\%, а карбонатность составляет 3-4\%. Пористость остается той же, что и в предыдущем интервале, а в показаниях проницаемости наблюдается рост.

Породы интервала 1750-1900 м характеризуются минимальным процентным содержанием псефитов (1-2 \%), псаммитов - до 32-33\%, алевритов и пелитов в сумме 61-63\%. Карбонатность пород данного состава - 5-6 \%, пористость - 25-26 \%, а проницаемость равна 150-155 мД.

Комплексы пород, расположенных на глубинах 1900-2050 м, характеризуются повторным резким (12-16 \%) ростом псефитов, у псаммитов этот показатель близок к 27-30 \%, у алевритов - к 36-38 \%, у пелитов - к 17-20\%. Содержание карбонатов - между 8-10\%. Пористость пород данного состава близка к 22-23 \%, проницаемость - около 110 мД.

В интервалах глубин 2050-2200 и 2200-2350 м наблюдается схожесть в изменениях петрофизических особенностей пород. Надо отметить, что процентное содержание псефитов составляет 13-14\%, псаммитов - $30 \%$, алевритов - приблизительно $28 \%$, а у пелитов уменьшение до 25-26 \%. Показатель карбонатности также уменьшается и достигает 4 \%. Относительно предедущего интервала пористость и проницаемость незначительно уменьшаются.

На глубинах 2350-2500 м в породах процентное содержание псефитов составляет в среднем $4 \%$, псаммитов - $24 \%$, алевритов - $42 \%$, а пелитов - $21 \%$. Пока- 
затель карбонатности, достигая максимума, составляет 9-11\%. Показатели пористости и проницаемости составляют, соответственно, 24-25 \% и 34-35 мД.

В породах, слагающих последний интервал глубин 2500-2650 м, за исключением псаммитовой фации, вышеуказанные параметры стабильно поддерживают свои тенденции.

На площади Гюрган-дениз изменение петрофизических особенностей пород по глубине начинается с интервала 400-550 м. Осадочный комплекс, сформи- ровавшийся на этом интервале, характеризуется малым суммарным содержанием псефитовой и псаммитовой фракций, составляющим приблизительно $8 \%$. Надо отметить, что алевриты характеризуются относительно высоким (57 \%) содержанием. Содержание же пелитов, по сравнению с последним, намного ниже $-25 \%$. Карбонатность на данном интервале глубин относительно высокая - 10 \%. Относительно высокая пористость оказывает положительное влияние на проницаемость пород - 250-260 мД (рис. 7).

\begin{tabular}{|c|c|c|c|c|c|c|c|}
\hline Глубина & Псефит & Псаммит & Алеврит & Пелит & Карбонатность & Пористость & Проницаемость \\
\hline $400-550$ & 3 & 5 & 57 & 25 & 10 & 22 & 26 \\
\hline $550-700$ & 2 & 12 & 39 & 42 & 5 & 12 & 90 \\
\hline $700-850$ & 4 & 6 & 40 & 43 & 7 & 16 & 190 \\
\hline $850-1000$ & 24 & 33 & 20 & 11 & 12 & 21 & 0 \\
\hline $1000-1150$ & 9 & 13 & 31 & 31 & 16 & 19 & 23 \\
\hline $1150-1300$ & 12 & 42 & 15 & 30 & 1 & 16 & 20 \\
\hline $1300-1450$ & 20 & 21 & 19 & 31 & 9 & 25 & 280 \\
\hline $1450-1600$ & 23 & 24 & 18 & 25 & 10 & 25 & 280 \\
\hline $1600-1750$ & 15 & 21 & 19 & 34 & 11 & 23 & 180 \\
\hline $1750-1900$ & 9 & 25 & 30 & 29 & 7 & 18 & 20 \\
\hline $1900-2050$ & 5 & 26 & 27 & 27 & 15 & 17 & 200 \\
\hline $2050-2200$ & 22 & 21 & 24 & 21 & 12 & 22 & 28 \\
\hline $2200-2350$ & 23 & 22 & 19 & 22 & 14 & 21 & 60 \\
\hline $2350-2500$ & 22 & 21 & 24 & 21 & 12 & 15 & 100 \\
\hline $2500-2650$ & 23 & 21 & 23 & 21 & 12 & 27 & 180 \\
\hline
\end{tabular}

Рис. 7. Гистограммы изменения петрофизических особенностей пород площади Гюрган-дениз от глубины. Деление на свиты: 400-1200 - сураханская, сабунчинская, балаханская; 1200-2600 - НКГ, НКП, КС, ПКС, КаС

Fig. 7. Histograms of changes in petrophysical characteristics of rocks Gyurgan-deniz square with the depth. Division into suites: 400-1200 - Surakhan, Sabunchu, Balakhan; 1200-2600-NKQ, NKP, KS, PKS, KaS

Пласты пород, охватывающих интервал 550-700 м, представлены в среднем на 2-3 \% псефитами, 12-15\%псаммитами и высоким суммарным содержанием 80-85 \% - алевритовой и пелитовой фаций. Этот интервал глубин характеризуется низкими значениями пористости и проницаемости. Основной причиной, вероятно, является низкое процентное (около $5 \%$ ) содержание карбонатов на фоне высокого процентного содержания алевритов и пелитов.

Породы интервала 700-850 м представлены до $4 \%$ псефитами, до $6 \%$ - псаммитами, до $40 \%$ - алевритами и до $43 \%$ - пелитами. Вышеотмеченная тенденция наблюдается и на этом интервале. В условиях резкого различия процентного содержания крупно- и мелкозернистых частиц и определенного роста карбонатности (7 \%) породы характеризуются низкими значениями пористости (15-16 \%) и проницаемости (180-190 мД).

На интервале 850-1000 м комплекс пород характеризуется следующим составом: $24 \%$ - псефиты, 33-35 \% - псаммиты, алевриты и пелиты с общим содержанием в $31 \%$. Карбонатность составляет $12 \%$. Породы с данным составом характеризуется хорошей отсортированностью и, в сравнении с предыдущими интервалами, высокой пористостью, что способствует увеличению значений проницаемости, которая достигает 240 мД [21].
Породы, представляющие следующий глубинный интервал - 1000-1150 м, составлены на $9 \%$ из псефитов, $13 \%$ - псаммитов, $31 \%$ - алевритов и настолько же - пелитовыми фациями. Карбонатность достигает своего максимального значения именно на этом интервале (16 \%), и этот рост сопровождается понижением значений пористости и проницаемости, достигая $18-19 \%$ и $230-235$ мД.

На глубине 1150-1300 м комплекс пород характеризуется следующим гранулометрическим составом: псефиты - 12-14 \%, псаммиты - 42-44 \%, алевриты 15-17 \% и пелиты - приблизительно 30 \%. Карбонатность резко уменьшается до 0-1\%. При таком составе пористость пород составляет 15-16 \%, а проницаемость около 215-220 мД.

Породы интервала 1300-1450 м представляют собой псефиты на 20-22 \%, псаммиты - $21 \%$, алевриты - $19 \%$ и пелиты - 31-32\%. По сравнению с предыдущим интервалом карбонатность пород здесь, резко увеличиваясь, достигает отметки в $9 \%$. При таком гранулярном составе породы имеют пористость 24-25\%, и проницаемость - 270-280 мД.

Четыре фации, образующие породы интервала 1450-1600 м, характеризуются следующим содержанием: псефиты - $23 \%$, псаммиты - $24 \%$, алевриты $18 \%$, пелиты - $25 \%$. Карбонатность - около $10 \%$. 
Пористость и проницаемость приблизительно идентичны предыдущему интервалу.

Интервал 1600-1750 м характеризуется $15 \%$ псефитами, $21 \%$ - псаммитами и $19 \%$ - алевритами и $34 \%$ пелитами. В условиях увеличении содержания пелитовой и карбонатной фаций (11 \%) значение проницаемости падает, достигая 180-185 мД.

Породы, соответствующие интервалу 1750-1900 м, составлены псефитами - 9 \%, псаммитами - $25 \%$, алевритами - $30 \%$ и незначительно меньшим содержанием пелитовой фации (29 \%). В условиях уменьшения карбонатности (7 \%) и пористости наблюдается увеличение проницаемости, значение которой достигает 215-220 мд.

Комплексы пород, представленные на интервале 1900-2050 м, характеризуются незначительным содержанием (5 \%) псефитов, приблизительно равным содержанием псаммитов, алевритов и пелитов в 26 , 27,27 \%. При значениях карбонатности 15 \% показатели пористости и проницаемости уменьшаются, соответственно, до 15-17\% и 200 мД.

Породы в промежутке глубин 2050-2200 м составлены псефитами на $22 \%$, псаммитами - $21 \%$, алевритами - $24 \%$ и пелитами - $21 \%$. Карбонатность падает до $12 \%$. Пористость - 21-22 \%, проницаемость 26-28 мд.

На интервалах 2200-2350 и 2500-2650 м наблюдается приблизительно одинаковое увеличение содержания псефитов, псаммитов, пелитов и карбонатности, сокращение алевритовой фации. Это положение оказывает отрицательное влияние на коллекторские свойства пород.

Из нижнего отдела ПТ (ПКС и КС) на двух месторождениях - Дарвин кюпеси и Гюрган-дениз, расположенных на исследуемой антиклинальной линии, были получены промышленные притоки нефти $[10,11]$. Свиты ПТ расположены на интервале глубин исследуемых нами пород. В коллекторских свойствах

\section{СПИСОК ЛИТЕРАТУРЫ}

1. Гусейнов Б.Б., Салманов А.М., Магеррамов Б.И. Нефтегазогеологическое районирование территории суши Азербайджана. - Баку: «Марс Принт», 2019. - 308 с.

2. Нариманов Н.Р., Гурбанов В.Ш. Прогноз перспектив нефтегазоносности выступов фундамента Южно-Каспийской мегавпадины // Вестник Пермского Национального Исследовательского Политехнического Университета. Геология, нефтегазовое и горное дело. - 2016. - № 19. - Т. 15. - С. 132-144.

3. Юсифов Х.М., Асланов Б.С. Нефтегазоносные бассейны Азербайджана. - Баку: Изд-во: «Марс Принт», 2018. - 324 с

4. Нариманов Н.Р. К тектонике Абшеронского архипелага // Азербайджанское нефтяное хозяйство. - 1992. - № 10. - С. 1-5.

5. Уточнение тектонического строения структуры Агбурундениз на основе новых геолого-геофизических данных, перспективности нефтегазоносности и открытия мезозойских отложений / Н.А. Меджидов, М.Н. Юсифов, А.К. Омаров, М.М. Сеидов, М.А. Мамедова // Азербайджанское нефтяное хозяйство. - 2015. - № 3. - С. 3-8.

6. Сулейманов А.М. Региональные структурно-тектонические особенности северо-западной части Абшеронского архипелага // Азербайджанское нефтяное хозяйство. - 2017. - № 4. - С. 3-11.

7. Мехтиев Р.Г., Омаров А.К. Нефтегазоносная перспективность миоцен-палеогеновых и мезозойских отложений Абшеронского архипелаг // Азербайджанское нефтяное хозяйство. 2004. - № 5. - C. 1-8. отложений ПТ в пределах интервала исследований по глубине на площадях Гошадаш, Агбурун-дениз, Дарвин кюпеси, Гюрган-дениз, расположенных на антиклинальной линии, не наблюдается (за исключением ряда интервалов) какой-либо закономерности. Учитывая вышеуказанное, можно высказать предположение о наличии скоплений углеводородов в отложениях нижнего ПТ в структурах Гошадаш и Агбурундениз, расположенных на той же антиклинальной линии, что и месторождения Дарвин кюпеси и Гюргандениз.

\section{Выводы}

1. Между коллекторскими свойствами и карбонатностью, глинистостью пород в изучаемом интервале глубин на площадях Гошадаш, Агбурундениз, Дарвин кюпеси, Гюрган-дениз наблюдается в основном обратное соотношение.

2. В особенностях изменения петрофизических параметров отложений продуктивной толщи по глубине на структурах Гошадаш, Агбурун-дениз, а также на месторождениях Дарвин кюпеси, Гюрган-дениз, за исключением некоторых коротких интервалов, не наблюдается какой-либо закономерности (т. е. линейности).

3. На основании фонтанов нефти дебитом 42 т/сут. из ПКС в скважине 726, пробуренной на месторождении Дарвин кюпеси, а также дебитом 20 т/сут. из КС в скважине 813 , полученной во время испытательных работ 10 т/сут. нефти из ПКС в скважине 7, пробуренной на месторождении Гюрган-дениз, и идентичной степени изменения коллекторских свойств пород в структурах Гошадаш и Агбурун-дениз, расположенных на той же антиклинальной линии, что и вышеуказанные месторождения, можно предположить наличие и в этих структурах углеводородных скоплений в одноименных отложениях.

8. Subsidence history and hydrocarbon migration modeling in South Caspian Basin / К.Н. Каграманов, М.С. Бабаев, Х.З. Мухтарова, С.Г. Шпырко // Вестник Киевского национального университета имени Т. Шевченко. Геология. - 2020. - № 1 (88). - С. 82-91.

9. Мухтарова Х.З. Особенности геологического строения и перспективы некоторых месторождений Абшеронского нефтегазоносного района // Азербайджанское нефтяное хозяйство. 2017. - № 2. - C. 3-13.

10. Мухтарова Х.З., Насибова Г.Д. Перспективы нефтегазоносности Северо-Абшеронского архипелага Южно-Каспийской впадины в связи с тектоническим развитием структур // Web of Scholar. Multidisciplinary Scientific Journal. - 2019. № 10 (40). - P. 16-23.

11. Атлас нефтегазоносных и перспективных структур Азербайджана / под ред. Т.А. Исмаил-заде. - Л.: Всесоюзный НИГИ, 1987. $-132 \mathrm{c}$.

12. Нариманов Н.Р., Бабаев М.С., Джахангиров Е.Х. Эффективная пористость и нефтенасыщение ПК, КС и НКП свит площади банка Дарвина в связи с особенностями распределения их фаций // Теоретические и практические аспекты современной науки: Материалы Международной (заочной) научнопрактической конференции. - Минск, 22 марта 2018. - Т. 2. C. $143-149$.

13. Мухтарова Х.З., Насибова Г.Д. О продуктивности и петрофизических характеристиках коллекторов северной части Бакинского архипелага // Web of Scholar. Multidisciplinary Scientific Journal. - 2019. - № 9 (39). - P. 21-29. 
14. Рыкус М.В. О влиянии вторичных преобразований на качество терригенных пород-коллекторов // Геология, геофизика и разработка нефтяных и газовых месторождений. - 2018. № 12. - C. 40-45.

15. Cannon S. Petrophysics: a practical guide. - India: Wiley\&Sons Ltd, 2015. - $224 \mathrm{p}$

16. Tiab D., Donaldson E.C. Petrophysics: theory and practice of measuring reservoir rock and fluid transport properties. Oklahoma: Elsevier, 2011. - 976 p.

17. Yang Shenglai. Fundamentals of Petrophysics. - China, 2017. $471 \mathrm{p}$.

18. Buryakovsky L.A., Chilingar G.V., Aminzadeh F. Petroleum geology of the South Caspian basin. - Boston: ButterworthHeinemann, 2001. - $442 \mathrm{p}$.

19. Sedimentation in a discharge dominated fluvial-lacustrine system: the Neogene productive series of the south Caspian Basin, Azerbaijan / D.J. Hinds, E. Aliyeva, M.B. Allen, C.E. Davies,
S.B. Kroonenberg, M.D. Simmons, S.J. Vinsent // Marine and Petroleum Geology. - 2004. - № 21. - P. 613-638.

20. Provenance patterns in a neotectonic basin: Pliocene and Quaternary sediment supply to the South Caspian / A. Morton, M. Allen, M. Simmons, F. Spathopoulos, J. Still, D. Hinds, A. Ismail-Zadeh, S. Kroonenberg // Basin Research. - 2003. V. 15. - P. 321-337.

21. Contrasting pliocene fluvial depositional systems within the rapidly subsiding south Caspian basin: a case study of the PaleoVolga and Paleo-Kura river systems in the Surakhany suite, upper productive series, onshore Azerbaijan / S.J. Vincent, C.E. Davies, K. Richard, E. Alieva // Marine and Petroleum Geology. - 2010. № 27. - P. 2079-2106.

Поступила 12.05.2021 2.

\section{Информация об авторах}

Myxmapoвa X.3. zызы, кандидат геолого-минералогических наук, доцент кафедры геологии нефти и газа Азербайджанский Государственный университет нефти и промышленности.

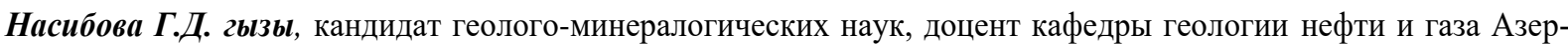
байджанский Государственный университет нефти и промышленности. 
UDC 553. 98(479.24): 550.8.072

\title{
EVALUATION OF OIL AND GAS CONTENT OF LOCAL UPLIFTS IN THE NORTH ABSHERON ZONE BASED ON PETROPHYSICAL PARAMETERS (LOCAL UPLIFTS GOSHADASH- AGBURUN-DENIZ-DARWIN KYUPESI-GYURGYAN-DENIZ AS AN EXAMPLE)
}

\author{
Khuraman Ziyadkhan kizi Mukhtarova1, \\ mukhtarova.khuraman@mail.ru \\ Gultar Jumshud kizi Nasibova ${ }^{1}$, \\ gultar_nasibova_1@yahoo.com \\ 1 Azerbaijan State Oil and Industry University, \\ 34, Azadlig avenue, Baku, AZ1010, Azerbaijan.
}

\begin{abstract}
The paper considers the properties of changes in the rocks petrophysical parameters of the local Goshadash, Agburun-deniz, Darwin kyupesi and Gyurgyan-deniz uplifts within the 400-2650 m depths interval, and the relevant diagrams were mapped. Analysis of the areal and depth changes in the petrophysical characteristics of rocks makes it possible to determine changes in their reservoir properties, as well as to relatively objectively assess both the fluid content and the prospects for the oil and gas potential of the reservoirs. Changes in the rock petrophysical properties and their impact upon porosity and permeability of the Goshadash, Agburun-deniz, Darwin kyupesi and Gyurgyan-deniz uplifts up to $2650 \mathrm{~m}$ deep were individually analyzed. The diagrams drawn based on petrophysical data show that psephitic, psammitic, silt and peliticfacies of terrigenous origin, as well as carbonate facies in the section in various ratios. As a rule, there is inverse relation between carbonate and shale content and reservoir properties and direct relation with grain sorting. This pattern is breached in exceptional cases, when reservoir properties are, probably, associated with increase in rock viscosity and formation of secondary porosity. Formation of secondary porosity at relatively greater depths, therefore, does not exclude the presence of hydrocarbon accumulations.
\end{abstract}

Relevance. The North Absheron uplifts zone, located close to rich oil and gas condensate fields, covers a large territory originating from the northwest of the Absheron peninsula and extending southeastwards. Goshadash, Agburun-deniz, Darwin kyupesi and Gyurgyan-deniz offshore uplifts under study are situated here. Productive series, that are the primary oil and gas bearing complex, are located at a relatively shallow depth, within the reach of modern technology. The construction and analysis of petrophysical models can play an important role in predicting oil and gas potential of the productive series and underlying sediments. This can lead to the discovery of new oil and gas accumulations and increase in oil production.

The aim of the research is to study the lithofacies and reservoir properties of rocks along the total depth based on petrophysical models built according to geological and geophysical data and well data.

Subject: productive series sediments of the Goshadash, Agburun-deniz, Darwin kyupesi and Gyurgyan-deniz fields.

Methods. The reservoir properties of sediments in the 400-2650 m depth interval of the Goshadash, Agburun-deniz, Darwin Kupesi and Gyurgan-deniz areas were researched on the basis of a laboratory study of core samples taken in wells. The above study interval was divided into several short intervals, each $150 \mathrm{~m}$ deep, and 20 to 40 core samples were taken from each interval, analysis was carried out, their particle size distribution, carbonate content, porosity and permeability were established. As a result of this analysis, for each of the $150 \mathrm{~m}$ intervals, the average values for the above parameters were presented, on the basis of which we built histograms.

Results. The inverse relationship is mainly observed between reservoir properties and carbonate and shale content within the depth interval under investigation in the fields of Goshadash, Agburun-deniz, Darwin kyupesi, Gyurgan-deniz. With the exception of some short intervals no pattern (i. e. linearity) is observed in the variation properties of petrophysical parameters of the productive series deposits along the depth in Goshadash, Agburun structures and Darwin kyupesi, Gurgan-deniz fields as well. Based on 42 ton/day flow rate of well 726 from PKS drilled at the Darwin kyupesi field and 20 ton/day flow rate of well 813 from KS oil gushers, 10 ton/day of oil obtained from PKS while testing well 7 drilled at the Gyurgan-deniz field and identical variation degree of rock reservoir properties in the Goshadash and Aghburun-deniz structures located on the same anticlinal line as the field above one can assume the presence of hydrocarbon accumulations in identical deposits of these structures.

\section{Key words:}

Sediments, petrophysical properties, pelites, psammites, silts, carbonate content, porosity, permeability.

\section{REFERENCES}

1. Guseynov B.B., Salmanov A.M., Magerramov B.I. Nefteqazogeologicheskoe rayonirovanie territorii sushi Azerbaydjana [Oil and gas geological zoning of the land territory of Azerbaijan]. Baku, Mars-Print Publ., 2019. 308 p.

2. Narimanov N.R., Gurbanov V.S. Forecast of the oil and gas potential of the basement ledges of the South Caspian megadepression. Vesnik Permskogo Natsionalnogo issledovatelskogo Politekhnicheskogo Universiteta. Geologiya, neftegazovoe i qornoe delo, 2016, no. 19, vol. 15, pp. 132-144. In Rus.

3. Yusifov Kh.M., Aslanov B.S. Neftegazonosnye basseyny Azerbaydjana [Oil and gas basins of Azerbaijan]. Baku, Mars Print Publ., 2018. 324 p.
4. Narimanov N.R. To the tectonics of the Absheron archipelago. Azerbaydjanskoe Neftanoe Khozyaystvo, 1992, no. 10, pp. 1-5. In Rus.

5. Medzhidov N.A., Yusifov M.N., Omarov A.K., Seidov M.M., Mamedova M.A. Clarification of the tectonic structure of the Agburun-deniz structure based on new geological and geophysical data, oil and gas potential and the discovery of Mesozoic deposits. Azerbaijan Oil Industry, 2015, no. 3, pp. 3-8.

6. Suleymanov A.M. Regional structural and tectonic features of the northwestern part of the Absheron archipelago. Azerbaijan Oil Industry, 2007, no. 4, pp. 3-11.

7. Mekhtiyev R.G., Omarov A.K. Oil and gas potential of the Miocene-Paleogene and Mesozoic deposits of the Absheron archipelago. Azerbaijan Oil Industry, 2004, no. 5, pp. 1-8. 
8. Kagramanov G.N., Babaev M.S., Mukhtarova Kh.Z., Shpirko S.G Subsidence history and hydrocarbon migration modeling in South Caspian Basin. Bulletin of the T. Shevchenko National University of Kyiv. Geology, 2020, no. 1 (88), pp. 82-91. In Rus.

9. Mukhtarova Kh.Z. Features of the geological structure and prospects of some fields of the Absheron oil and gas region. Azerbaijan Oil Industry, 2017, no. 2, pp. 3-13.

10. Mukhtarova Kh.Z., Nasibova G.J. Prospects for the oil and gas content of the North Absheron archipelago of the South Caspian depression in connection with the tectonic development of structures. Web of Scholar. Multidisciplinary Scientific Journal, 2019, no. 10 (40), pp. 16-23. In Rus.

11. Atlas neftegazonosnykh i perspektivnykh struktur Azerbayjana [Atlas of oil and gas and prospective structures of Azerbaijan]. Ed. by T.A. İsmail-zade. Leninqrad, Vsesoyuzny NIGI, 1987. $132 \mathrm{p}$.

12. Narimanov N.R., Babaev M.S., Dzhakhangirov E.Kh. Effektivnaya poristost i neftenasishenie podkirmakinskoy (PK), kirmakinskoy (KS) i nadkirmakinskoy (NK) svit ploshchadi Darvina v svyazi s osobennostyami raspredeleniya ikh fatsiy [Effective porosity and oil saturation under the Kirmakinskaya, Kirmakinskaya and above the Kirmakinskaya formations of the Darwin Jug area due to the peculiarities of the distribution of their facies]. Teoreticheskie i prakticheskie aspekty sovremennoy nauki. Materialy Mezhdunarodnoy (zaochnoy) nauchno-prakticheskoy konferentsii [Theoretical and practical aspects of modern science. Materials of the International (correspondence) scientific-practical conference]. Minsk, 22 March 2018. No. 2, pp. 143-149.

13. Mukhtarova Kh.Z., Nasibova G.J. On productivity and petrophysical characteristics of reservoirs in the northern part of the Baku archipelago. Web of Scholar. Multidisciplinary Scientific Journal, 2019, no. 9 (39), pp. 21-29. In Rus.
14. Rikus M.V. On the influence of secondary transformations on the quality of terrigenous reservoir rocks. Geology, geophysics and development of oil and gas fields, 2018, no. 12, pp. 40-45. In Rus.

15. Cannon S. Petrophysics: a practical guide. India, Wiley\&Sons Ltd, 2015. - $224 \mathrm{p}$.

16. Tiab D., Donaldson E.C. Petrophysics: theory and practice of measuring reservoir rock and fluid transport properties. Oklahoma, Elsevier, 2011. 976 p.

17. Yang Shenglai. Fundamentals of petrophysics. China, Электронная книга, 2017. 471 p.

18. Buryakovsky L.A., Chilingar G.V., Aminzadeh F. Petroleum geology of the South Caspian Basin. Boston, ButterworthHeinemann, 2001. $442 \mathrm{p}$

19. Hinds D.J., Aliyeva E., Allen M.B., Davies C.E., Kroonenberg S.B., Simmons M.D., Vinsent S.J. Sedimentation in a discharge dominated fluvial-lacustrine system: the Neogene productive series of the south Caspian Basin, Azerbaijan. Marine and Petroleum Geology, 2004, no. 21, pp. 613-638.

20. Morton A., Allen M., Simmons M., Spathopoulos F., Still J., Hinds D., Ismail-Zadeh A., Kroonenberg S. Provenance patterns in a neotectonic basin: Pliocene and Quaternary sediment supply to the South Caspian. Basin Research, 2003, vol. 15, pp. 321-337.

21. Vincent S.J., Davies C.E., Richard K., Alieva E. Contrasting pliocene fluvial depositional systems within the rapidly subsiding south Caspian basin: a case study of the Paleo-Volga and PaleoKura river systems in the Surakhany suite, upper productive series, onshore Azerbaijan. Marine and Petroleum Geology, 2010, no. 27, pp. 2079-2106.

Received: 12 May 2021.

\section{Information about the authors}

Khuraman Ziyadkhan kizi Mukhtarova, Cand. Sc., associate professor, Azerbaijan State Oil and Industry University. Gultar Jumshud kizi Nasibova, Cand. Sc., associate professor, Azerbaijan State Oil and Industry University. 